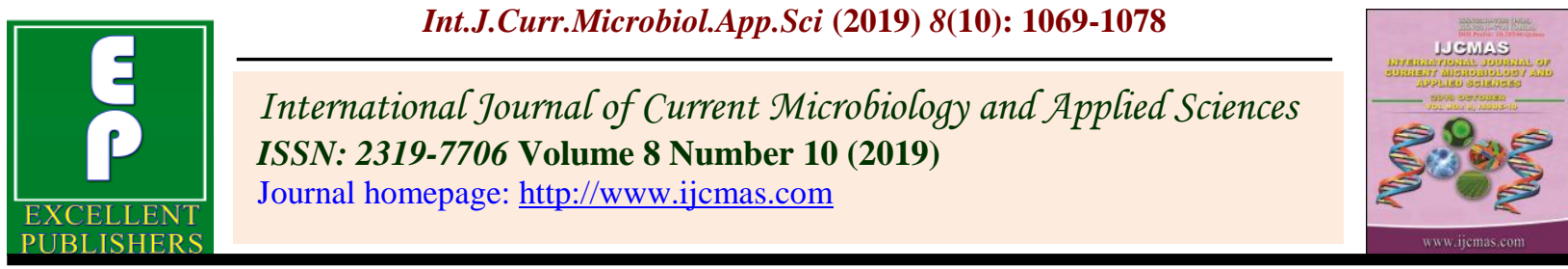

Original Research Article https://doi.org/10.20546/ijcmas.2019.810.126

\title{
Occurrence and Distribution of Anthracnose of Chilliin Marathwada Region of Maharashtra State, India
}

\author{
S.L. Badgujar*, D.N. Dhutraj and C.V. Ambadkar \\ Department of Plant Pathology, College of Agriculture, VNMKV, Parbhani, India \\ *Corresponding author
}

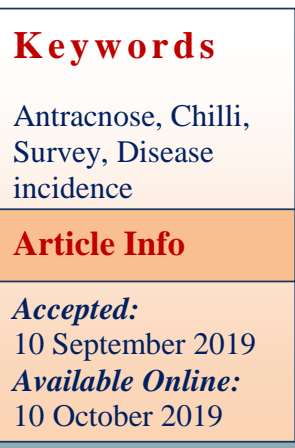

\section{Introduction}

Chilli (Capsicum annuumL) also called as red pepper is an important spice-cum-vegetable crop of the world. India is the largest producer of dry chilli in the world. However, it suffers from biotic diseases caused by fungi, bacteria, viruses and nematodes resulting in huge loss of the crop. Among the fungal diseases infecting chilli crop, anthracnose or ripe fruit rot caused by Colletotrichum capsici (Syd.) Butler and Bisby has become a serious problem limiting the profitable cultivation and seed production throughout the major chilli growing regions of India (Gopinath et al., 2006; Ramachandran et al., 2008).
Anthracnose is one of the most economically important disease reducing marketable yields from 10 to 80 per cent of the crop production in some developing countries (Poonpolgul and Kumphai, 2007). It is the major problem on matured fruits, causing severe losses due to both pre and post-harvest fruit decay (Hadden and Black, 1989; Bosland and Votava, 2003). The market value and nutritive value is degraded in infected fruits resulting in poor quality seed. Considering economic importance of antracnose of chilli, present studies were conducted to survey the disease in eight districts of Marathwada region of Maharashtra state. 


\section{Materials and Methods}

A roving survey of randomly selected chilli crop fields, covering three Agro-climatic zones viz., Scarcity Zone (SZ), Assured Rainfall Zone (ARZ) and Moderate Rainfall Zone (MRZ) of Marathwada region of the Maharashtra state was undertaken, during the year 2017-18 and 2018-19, to assess fruit rot disease incidence and simultaneously to collect the disease samples. Chilli growing pockets / fields were identified from the records available at the office of SubDivisional Agriculture Officers of the respective districts.

In the selected chilli crop fields, a $10 \mathrm{~m}^{2}$ area was randomly selected and in that counted total number of chilli plants and number of plants showing typical fruit rot symptoms was recorded and per cent fruit rot disease incidence and intensity was calculated by using following formula.

Per cent Disease Incidence

No. of Plants Infected

Total no. of Plants Observed

\section{Results and Discussion}

A roving survey to record anthracnose incidence was conducted during the year 2017-18 and 2018-19, covering 184 and 189 chilli crop fields of 08 districts, distributed under three agro-climatic zones viz., Scarcity zone (03), Assured Rainfall zone (07) and Moderate rainfall zone (02) of Marathwada region of the Maharashtra state.

The results so obtained on anthracnose incidence are interpretedtahsil-wise in Table 1, district-wise in Table 2, chilli variety-wise in Table 3 and agro-climatic zone-wise in Table 4 (Fig. 1-6).
Tehsil-wise disease incidence of chillianthracnose

The results (Table 1) indicated a wide range of anthracnose disease incidence, during both the years of survey and it was ranged from 27.29 (Umarga) to 66.00 (Kandhar) and 25.61 (Tuljapur) to 53.72 (Loha) per cent, during the year 2017-18 and 2018-19 seasons, respectively. However, maximum anthracnose disease incidence was recorded in Kandhar tehsil (66.00\%), during the year 2017-18, followed by Himayatnagar tehsil $(64.68 \%)$ and Ardhapur tehsil (60.31\%), whereas, maximum anthracnose disease incidence was recorded in Loha tehsil (53.72 \%), respectively during the year, 2018-19, followed by Naigaon tehsil $(53.34 \%)$ and Ardhaur tehsil (51.70\%).

Rest of the tehsils recorded anthracnose disease incidence in the range of 28.34 (Kalamb) to 58.66 (Mudkhed) per cent and 27.55 (Kalamb) to 53.34 (Naigaon) per cent, during the year, 2017-18 and 2018-19 seasons, respectively. The minimum disease incidence was recorded in Umarga tehsil (27.29 \%), during the year 2017-18, followed by Kalamb tehsil $(28.29 \%)$ and Tuljapur tehsil (30.26\%), whereas during the year 2018-19 the minimum disease incidence was recorded in Umarga tehsil $(25.61 \%)$ followed by Kalamb (27.55\%) and Umarga tehsil (28.25\%).

\section{District-wise disease incidence of anthracnose of chilli}

The results revealed that maximum anthracnose disease incidence of 56.72 and 47.98 per cent was observed in Nanded district, during the year 2017-18 and 2018-19 respectively, with maximum pooled incidence of 52.35 per cent. This was followed by the districts of viz., Aurangabad (52.08\%, 43.14 $\%$ and $47.61 \%$ ), Hingoli $(46.07 \%, 42.18 \%$ and $44.12 \%)$, Beed $(44.62 \%, 37.09 \%$ and 
$40.85 \%)$, Parbhani $(43.47 \%, 38.64 \%$ and $41.06 \%)$, Jalna (41.43 \%, $34.61 \%$ and 38.08 $\%)$, Latur (35.86 \%, $32.29 \%$ and $34.07 \%)$ and Osmanabad (31.35 \%, $28.85 \%$ and 30.10). Overall average anthracnose disease incidence was maximum (43.95\%) during the year, 2017-18and was comparatively minimum (38.10\%) during the year, 2018-19.
Variety-wise chilli anthracnose incidence

The result revealed that in Marathwada region, the chilli varieties purchased from local market are popularly grown by the farmers.

Table.1 Tehsil wise incidence of chilli anthracnose in the districts of Marathwada during the year 2017-18 and 2018-19

\begin{tabular}{|c|c|c|c|c|c|c|}
\hline \multirow{2}{*}{$\begin{array}{l}\text { Sr. } \\
\text { No. }\end{array}$} & \multirow[t]{2}{*}{ Districts } & \multirow[t]{2}{*}{ Tehsils } & \multicolumn{2}{|c|}{ 2017-18 } & \multicolumn{2}{|c|}{ 2018-19 } \\
\hline & & & $\begin{array}{l}\text { No. of } \\
\text { Fields }\end{array}$ & $\begin{array}{c}\text { Average } \\
\text { Incidence } \\
(\%)\end{array}$ & $\begin{array}{l}\text { No. of } \\
\text { Fields }\end{array}$ & $\begin{array}{c}\text { Average } \\
\text { Incidence } \\
(\%)\end{array}$ \\
\hline \multicolumn{7}{|c|}{ Scarcity zone } \\
\hline \multirow[t]{2}{*}{1.} & \multirow[t]{2}{*}{ Aurangabad } & Vaijapur & 3 & 54.19 & 3 & 47.37 \\
\hline & & Gangapur & 4 & 53.65 & 1 & 46.43 \\
\hline \multirow[t]{3}{*}{2.} & \multirow[t]{3}{*}{ Beed } & Kej & 3 & 47.10 & 2 & 40.24 \\
\hline & & Georai & 1 & 35.21 & 2 & 33.37 \\
\hline & & Parli & 2 & 39.42 & 4 & 35.34 \\
\hline \multirow[t]{2}{*}{3.} & \multirow[t]{2}{*}{ Osmanabad } & Bhoom & 3 & 36.77 & 1 & 32.00 \\
\hline & & Paranda & 2 & 33.00 & 4 & 30.36 \\
\hline \multicolumn{3}{|c|}{ Overall Average / Total: } & 18 & 42.76 & 17 & 37.87 \\
\hline \multicolumn{7}{|c|}{ Assured rainfall zone } \\
\hline \multirow[t]{4}{*}{1.} & \multirow[t]{4}{*}{ Aurangabad } & Paithan & 2 & 47.70 & 3 & 38.91 \\
\hline & & Aurangabad & 3 & 54.24 & 2 & 47.31 \\
\hline & & Phulmbri & 1 & 47.42 & 4 & 37.67 \\
\hline & & Sillod & 4 & 55.27 & 1 & 41.16 \\
\hline \multirow[t]{6}{*}{2.} & \multirow[t]{6}{*}{ Jalna } & Jalna & 3 & 43.24 & 4 & 37.65 \\
\hline & & Bhokardan & 3 & 41.10 & 4 & 33.54 \\
\hline & & Ambad & 4 & 45.29 & 3 & 35.50 \\
\hline & & Jafrabad & 2 & 36.43 & 3 & 36.64 \\
\hline & & Partur & 2 & 38.06 & 4 & 34.00 \\
\hline & & Mantha & 3 & 44.44 & 2 & 30.33 \\
\hline \multirow[t]{6}{*}{3.} & \multirow[t]{6}{*}{ Beed } & Georai & 1 & 55.27 & 4 & 35.10 \\
\hline & & Beed & 5 & 36.43 & 2 & 36.38 \\
\hline & & Majalgaon & 2 & 54.24 & 3 & 39.00 \\
\hline & & Kej & 4 & 42.94 & 3 & 33.71 \\
\hline & & Ambajogai & 2 & 47.70 & 4 & 31.30 \\
\hline & & Parli & 3 & 43.24 & 1 & 49.00 \\
\hline 4. & Osmanabad & Osmanabad & 4 & 32.44 & 3 & 29.33 \\
\hline
\end{tabular}




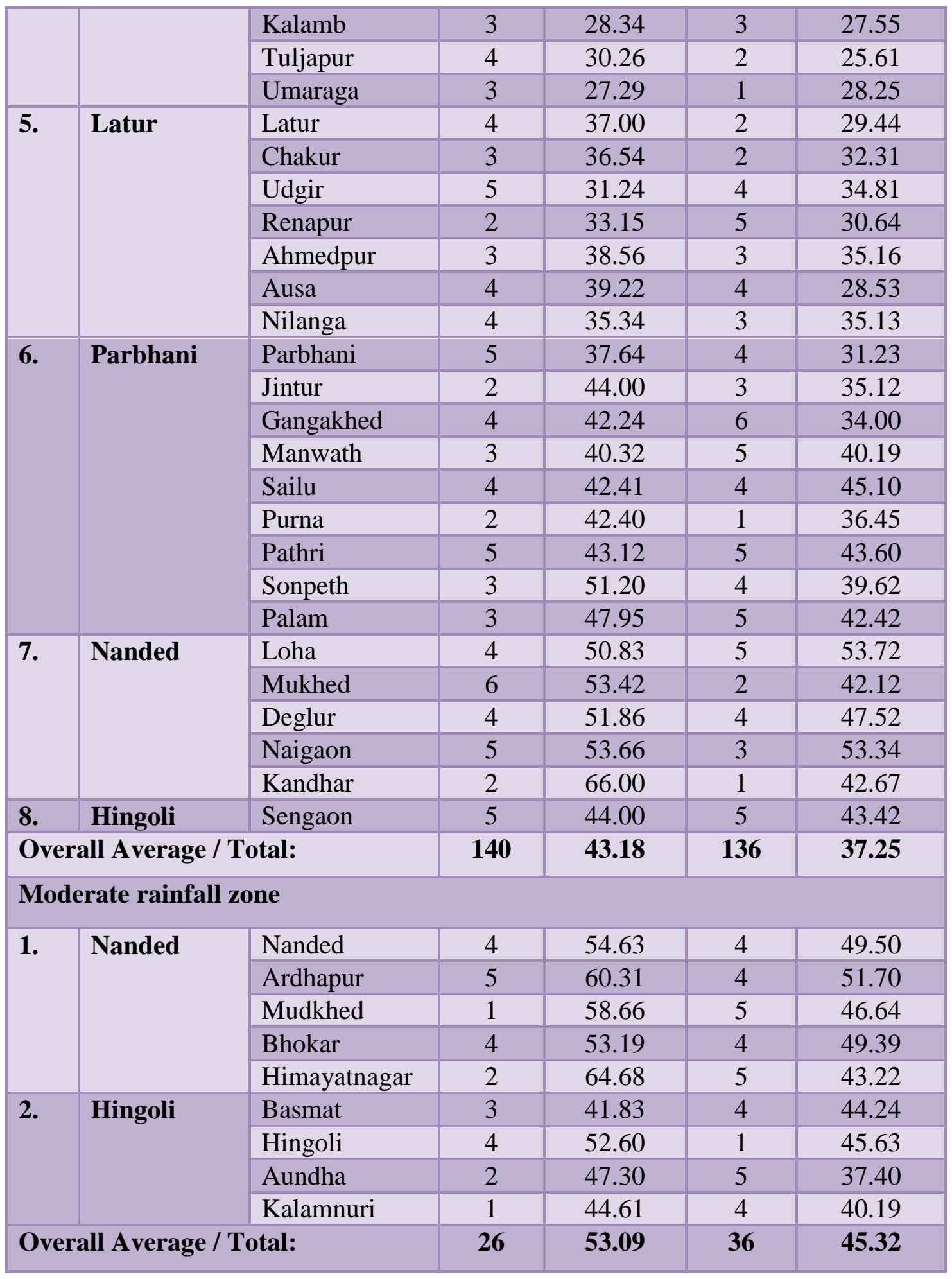


Table.2 District-wise chilli anthracnose incidence, during the year 2017-18 and 2018-19

\begin{tabular}{|l|c|c|c|c|c|}
\hline \multirow{2}{*}{ Districts } & \multicolumn{2}{|c|}{ No. of Locations } & \multicolumn{2}{c|}{ Av. Incidence (\%) } & Pooled Mean \\
\cline { 2 - 6 } & $\mathbf{2 0 1 7 - 1 8}$ & $\mathbf{2 0 1 8 - 1 9}$ & $\mathbf{2 0 1 7 - 1 8}$ & $\mathbf{2 0 1 8 - 1 9}$ & $(\%)$ \\
\hline Aurangabad & 17 & 14 & 52.08 & 43.14 & 47.61 \\
\hline Beed & 23 & 25 & 44.62 & 37.09 & 40.85 \\
\hline Hingoli & 15 & 19 & 46.07 & 42.18 & 44.12 \\
\hline Jalna & 17 & 20 & 41.43 & 34.61 & 38.02 \\
\hline Latur & 25 & 23 & 35.86 & 32.29 & 34.07 \\
\hline Nanded & 37 & 37 & 56.72 & 47.98 & 52.35 \\
\hline Osmanabad & 19 & 14 & 31.35 & 28.85 & 30.10 \\
\hline Parbhani & 31 & 37 & 43.47 & 38.64 & 41.06 \\
\hline $\begin{array}{l}\text { Overall Average / } \\
\text { Total }\end{array}$ & $\mathbf{1 8 4}$ & $\mathbf{1 8 9}$ & $\mathbf{4 3 . 9 5}$ & $\mathbf{3 8 . 1 0}$ & $-\mathbf{-}$ \\
\hline
\end{tabular}

Table.3 Variety wise chilli anthracnose incidence, during the year, 2017-18 and 2018-19

\begin{tabular}{|c|l|c|c|c|c|c|}
\hline \multirow{2}{*}{$\begin{array}{c}\text { Sr. } \\
\text { No. }\end{array}$} & \multicolumn{1}{|c|}{$\begin{array}{c}\text { Chilli } \\
\text { Varieties }\end{array}$} & \multicolumn{2}{|c|}{ No. of locations } & \multicolumn{2}{c|}{ Av. Incidence (\%) } & $\begin{array}{c}\text { Pooled Mean } \\
\text { Incidence (\%) }\end{array}$ \\
\cline { 3 - 7 } & & $\mathbf{2 0 1 7 - 1 8}$ & $\mathbf{2 0 1 8 - 1 9}$ & $\mathbf{2 0 1 7 - 1 8}$ & $\mathbf{2 0 1 8 - 1 9}$ & \\
\hline $\mathbf{1}$ & KSP-1194 & 14 & 7 & 48.48 & 33.21 & 40.85 \\
\hline $\mathbf{2}$ & Arch-930 & 12 & 10 & 45.83 & 41.25 & 43.54 \\
\hline $\mathbf{3}$ & Amulya & 15 & 13 & 47.54 & 45.45 & 46.49 \\
\hline $\mathbf{4}$ & Green Gold & 18 & 11 & 39.93 & 37.33 & 38.63 \\
\hline $\mathbf{5}$ & Garima & 11 & 23 & 47.17 & 46.47 & 46.82 \\
\hline $\mathbf{6}$ & Local & 18 & 19 & 48.95 & 37.71 & 43.33 \\
\hline $\mathbf{7}$ & Parbhani Tejas & 7 & 18 & 47.64 & 39.12 & 43.38 \\
\hline $\mathbf{8}$ & Sitara & 17 & 7 & 37.43 & 31.17 & 34.30 \\
\hline $\mathbf{9}$ & Teja-4 & $\mathbf{5}$ & 17 & 40.32 & 33.51 & 36.91 \\
\hline $\mathbf{1 0}$ & Jwala & 8 & 7 & 39.48 & 42.07 & 40.77 \\
\hline $\mathbf{1 1}$ & Pragati & 14 & 16 & 40.74 & 31.83 & 36.28 \\
\hline Overall & Average / Total & $\mathbf{1 8 4}$ & $\mathbf{1 8 9}$ & $\mathbf{4 3 . 9 5}$ & $\mathbf{3 8 . 1 0}$ & - \\
\hline
\end{tabular}


Table.4 Agro-climatic zone-wise chilli anthracnose incidence, during the year, 2017-18 and 2018-19

\begin{tabular}{|c|l|c|c|c|c|c|}
\hline \multirow{2}{*}{$\begin{array}{l}\text { Sr. } \\
\text { No }\end{array}$} & Agro-climatic Zone & \multicolumn{2}{|c|}{ No of locations } & \multicolumn{2}{c|}{ Av. Incidence (\%) } & $\begin{array}{c}\text { Pooled Mean } \\
\text { Incidence (\%) }\end{array}$ \\
\cline { 3 - 6 } & & $\mathbf{2 0 1 7 - 1 8}$ & $\mathbf{2 0 1 8 - 1 9}$ & $\mathbf{2 0 1 7 - 1 8}$ & $\mathbf{2 0 1 8 - 1 9}$ & \\
\hline $\mathbf{1}$ & Scarcity zone & 18 & 17 & 42.76 & 37.87 & 40.31 \\
\hline $\mathbf{2}$ & Assured rainfall zone & 140 & 136 & 43.18 & 37.28 & 40.23 \\
\hline $\mathbf{3}$ & Moderate rainfall zone & 26 & 36 & 53.09 & 45.32 & 49.20 \\
\hline & Overall Average/ Total & $\mathbf{1 8 4}$ & $\mathbf{1 8 9}$ & $\mathbf{4 6 . 3 4}$ & $\mathbf{4 0 . 1 6}$ & $\mathbf{4 3 . 2 5}$ \\
\hline
\end{tabular}

Fig.1 District-wise incidence of chilli anthracnose in Marathwada region

(During the year 2017-18 and 2018-19)

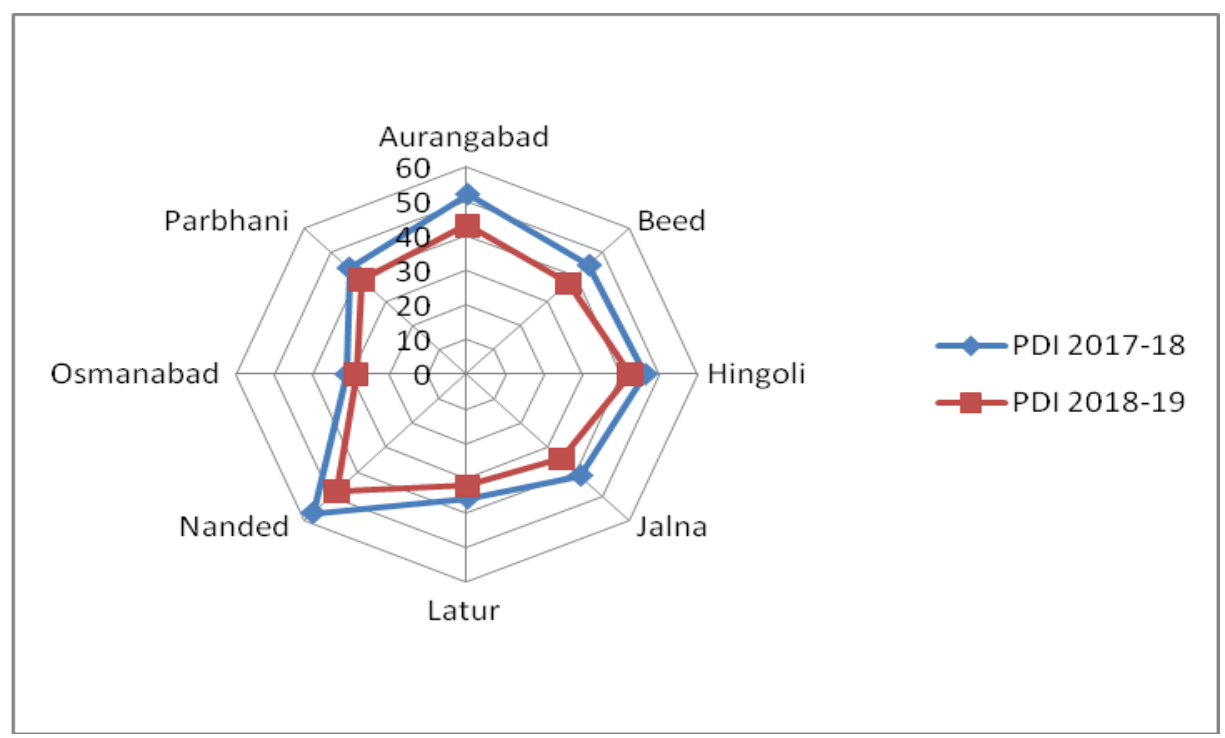

Fig.2 District-wise pooled mean incidence of chilli anthracnose in Marathwada region (During the year 2017-18 and 2018-19)

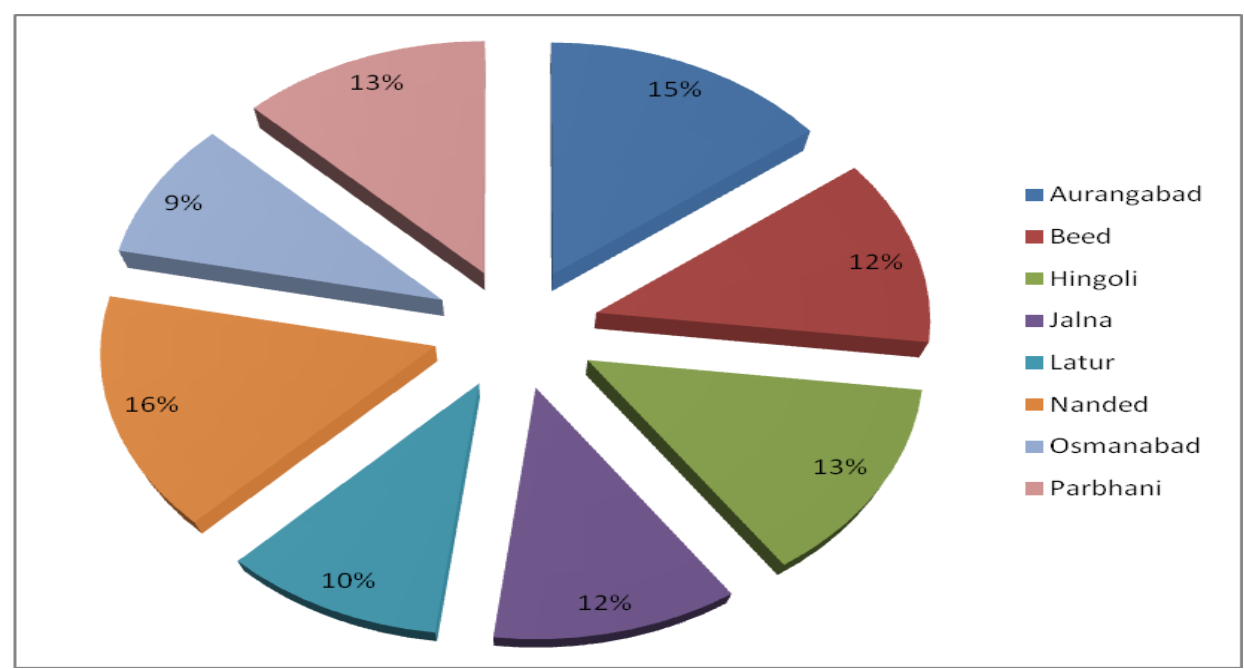


Fig.3 Variety-wise incidence of chilli anthracnose in Marathwada region

(During the year 2017-18 and 2018-19)

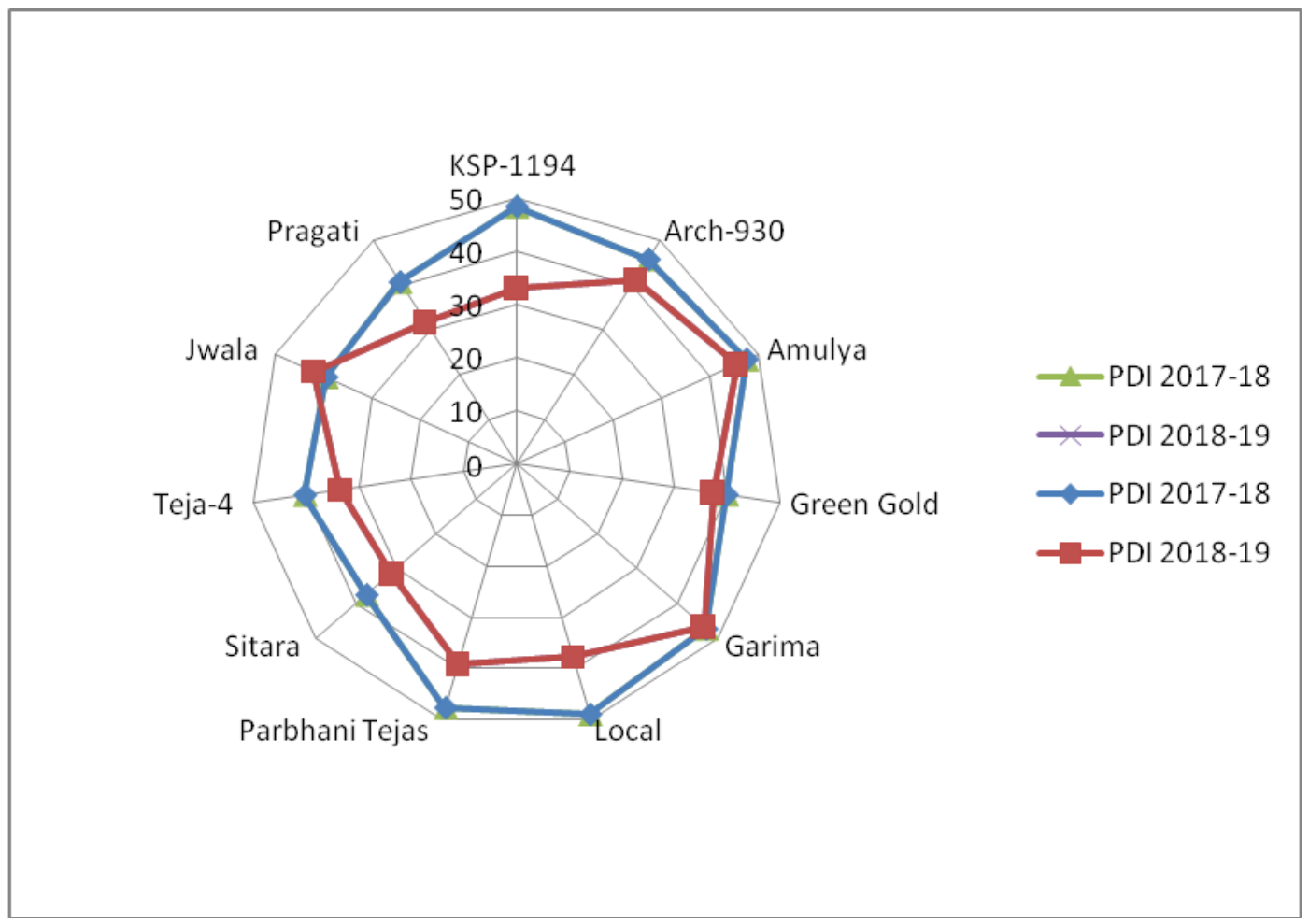

Fig.4 Variety-wise pooled mean incidence of chilli anthracnose in Marathwada region (During the year 2017-18 and 2018-19)

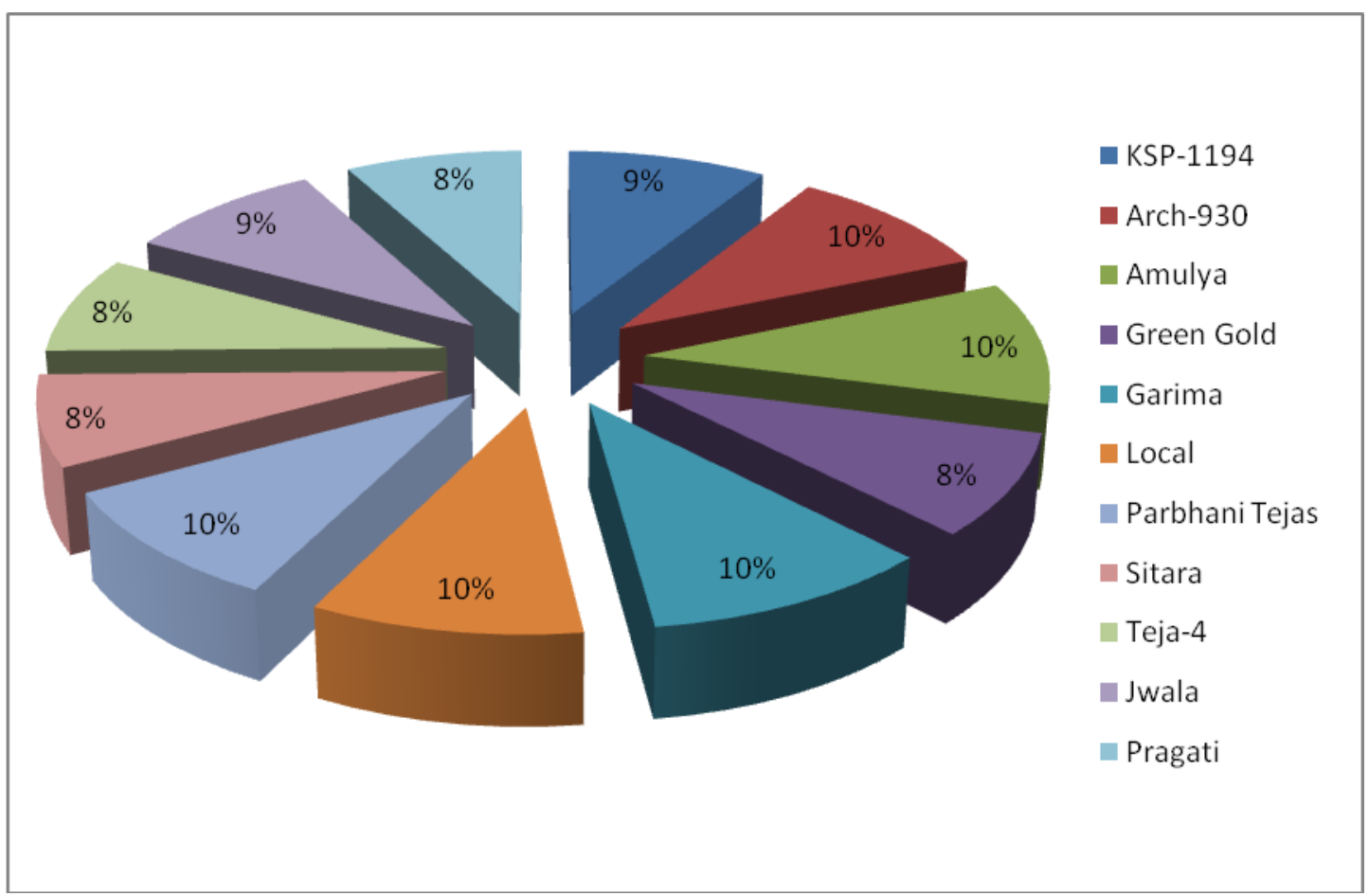


Fig.5 Agro-climatic zone wise incidence of chilli anthracnose in Marathwada region (During the year 2017-18 and 2018-19)

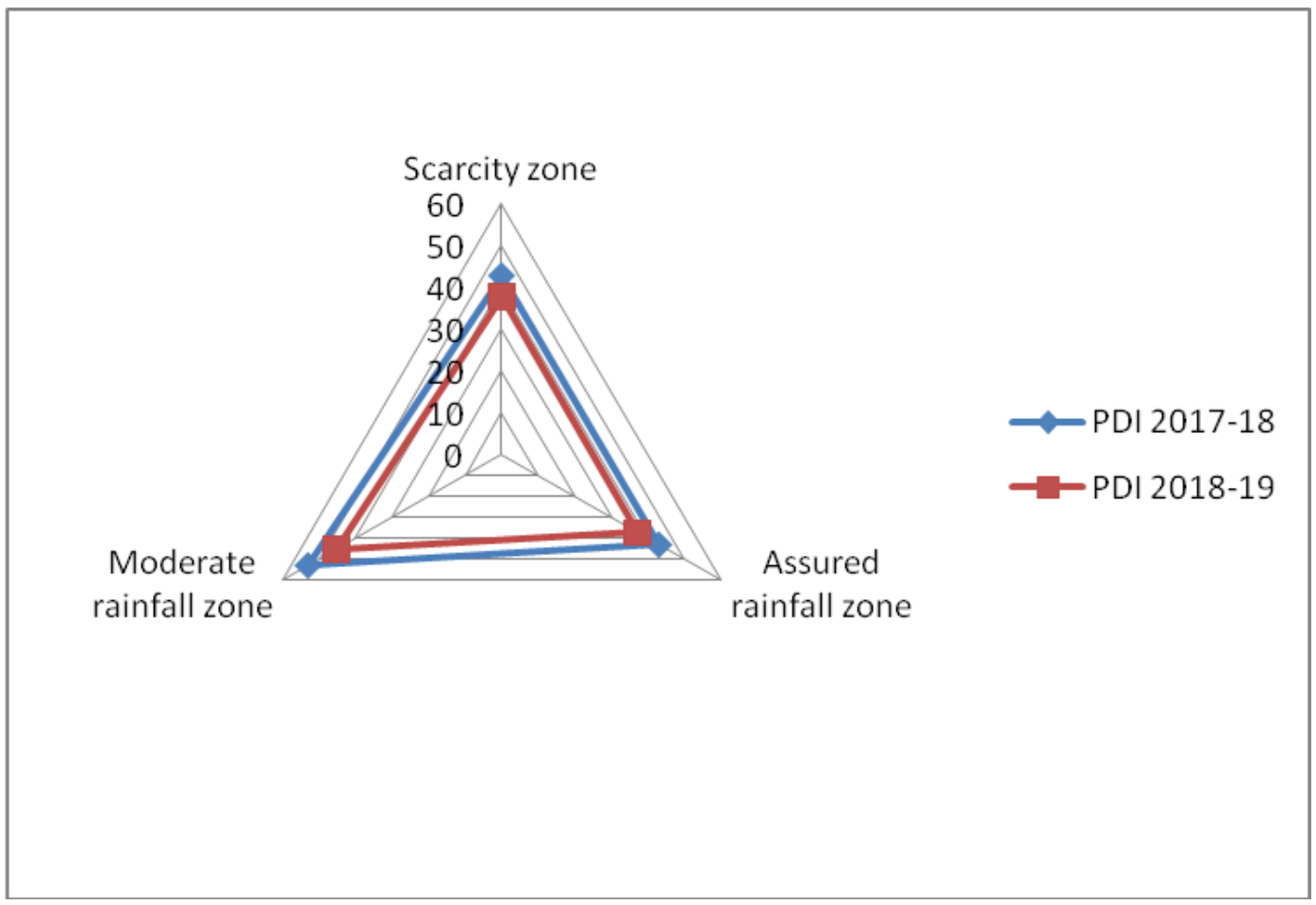

Fig.6 Agro-climatic zone wise pooled mean incidence of chilli anthracnose in Marathwada region (During the year 2017-18 and 2018-19)

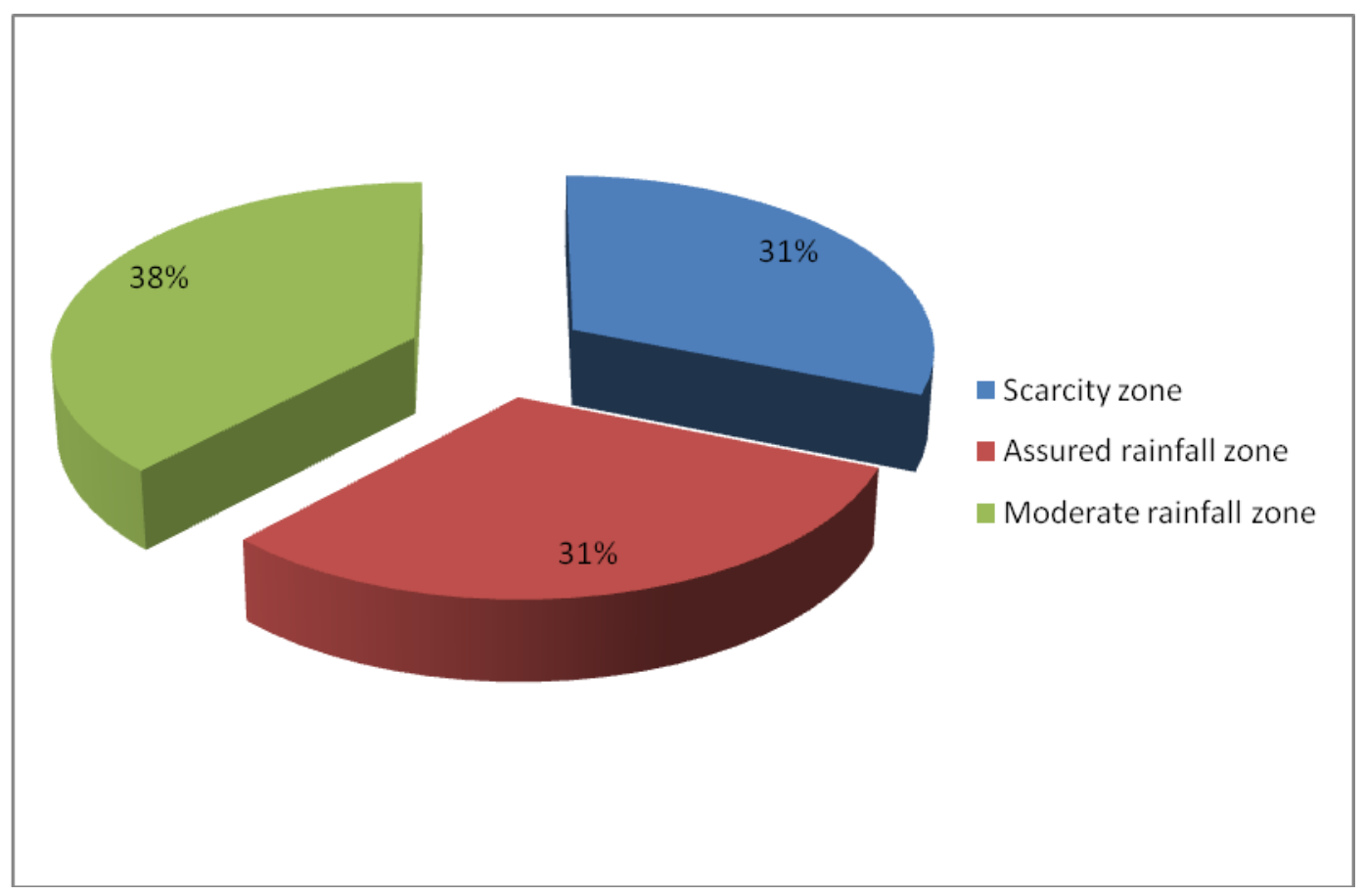


Among overall 11 chilli varieties grown by the farmers of the Marathwada region surveyed (2017-18 and 2018-19), maximum anthracnose disease incidence was found in Local variety (48.95\%), during the year, 2017-18. This was followed by the varieties viz., KSP 1194 (48.48 \%), Parbhani Tejas (47.64 \%) and Amulya (47.54 \%) and maximum anthracnose disease incidence was found in Garima (46.47 \%), during the year, 2018-19. This was followed by the varieties viz., Amulya (45.45\%), Jwala (42.07\%) and Arch-930 (41.25\%). In rest of the varieties, the anthracnose incidence was ranged from 37.43 to 47.17 per cent and 31.17 to 39.12 per cent during the year, 2017-18 and 2018-19 respectively, with pooled mean incidence in the range of 12.01 to 35.80 per cent.

\section{Agro-climatic zone-wise disease incidence of chilli anthracnose}

The results revealed that among three agroclimatic zones viz., Scarcity zone (SZ), Assured rainfall zone (ARZ) and Moderate rainfall zone (MRZ) surveyed, maximum anthracnose disease incidence of 53.09 and 45.32 per cent was observed during the year 2017-18 and 2018-19 respectively, with maximum pooled mean incidence of 49.20 per cent in Moderate Rainfall zone, followed by Scarcity Zone $(42.76 \%, 37.87 \%$ and $40.31 \%)$ and Assured rainfall zone (43.18\%, $37.28 \%$ and $40.23 \%)$. Overall average anthracnose incidence was maximum (46.34 $\%)$ during the year, 2017-18and was comparatively minimum $(40.16 \%)$ during the year, 2018-19.

From the results it has been inferred that anthracnose of chilli disease incidence varied at different locations of Marathwada region falling under various agro-climatic conditions, inoculum potential and varieties cultivated with different genetic makeup.
The results of the present studies are in accordance with results of previous workers who worked on antracnose of chilli. Thind and Jhooty (1985) conducted surveys of major chilli growing areas of Punjab during the year 1979-1982 and reported that $C$. capsiciwas widely prevalent and most damaging in all the areas surveyed and its incidence was varied between 66 to 84 per cent.Angadi (1999) carried out survey for the incidence of anthracnose of chilli caused by C. capsiciin Raichur, Dharwad and Gadag districts. The disease was more prevalent in Raichur district than in Dharwad and Gadag districts. Ramachandran et al., (2008) revealed that $C$. capsici as the most predominant species in the major chilli growing states of Karnataka and Andra Pradesh in India. Similar reports were also given by Sawant et al., (2012), Katoch et al., (2016), Saini et al., (2016) and Yahaya et al., (2016).

\section{References}

Angadi, H. D. (1999). Studies on anthracnose of chilli (Capsicum annum) and its management. M. Sc. (Agri.) Thesis, Univ. Agric. Sci., Bangalore, Karnataka, India.

Bosland, P.W. and Votava, E.J. (2003). Peppers: Vegetable and Spice Capsicum. England: CAB International. p. 233.

Gopinath, K., Radhakrishnan, N.V. and Jayaral. J. (2006). Effect of propiconazole and difenoconazole on the control of anthracnose of chilli fruit caused by Collectotrichum capsici. Crop Prot., 25: 1024-1031.

Hadden, J.F. and Black, L.L. (1987). Comparison of virulence of tomato and pepper isolates of Colletotrichum spp. (Abstr.). Phytopath., 77: 641.

Katoch A., Sharma P. and Sharma P. N. (2016). Identification of Colletotrichum 
spp. associated with fruit rot of Capsicum annuum in North Western Himalayan region of India using fungal DNA barcode markers. J. Plant Biochem. Biotechnol., 1-9.

Poonpolgul, S. and Kumphai, S. (2007). Chilli/Pepper anthracnose in Thailand country report. In: Oh, D.G. and Kim, K.T. (edi.) Abstract of the First International Symposium on Chilli Anthracnose. Republic of Korea: National Horticultural Research Institute, Rural Development and Administration. pp. 23.

Ramachandran, N., Madhavi, R.K. and Rathanmma, K. (2008). Current Status of Chilli Anthracnose in India.(Abst.). First International Symposium on Chilli Anthracnose, Sept, 17-19, 2007, Hoam Faculty House, Seoul National Univ., Seoul, Korea. pp. 26.

Saini T.J., Gupta S.G., Char B.R., Zehr U.B. and Anandalakshmi R. (2016). First report of chilli anthracnose caused by Colletotrichum karstii in India. New Disease Reports., 34: 6.

Sawant, I.S., Narkar, S.P., Shetty, D.S., Upadhyay, A. and Sawant, S.D. (2012). First report of Colletotrichum capsici causing anthracnose on grapes in Maharashtra, India. New Disease Reports, 25: 2.

Thind, T.S. and Jhooty, J.S. (1985).Relative prevalence of fungal diseases of chilli fruit in Punjab. Indian J. Mycol. Pl. Pathol., 15 (3): 305-307.

Yahaya S.M., Fagwalawa L.D., Ali M.U., Lawan M. and Mahmud S. (2016). Isolation and Identification of Pathogenic Fungi Causing Deterioration of Lettuce Plant (Lactuca sativa) A Case Study of Yankaba and Sharada Vegetables Markets. Journal of Plant Science \& Research., (2016) 3(1): 1-4.

\section{How to cite this article:}

Badgujar, S.L., D.N. Dhutraj and Ambadkar, C.V. 2019. Occurrence and Distribution of Anthracnose of Chilliin Marathwada Region of Maharashtra State, India. Int.J.Curr.Microbiol.App.Sci. 8(10): 1069-1078. doi: https://doi.org/10.20546/ijcmas.2019.810.126 